\title{
The Effect of Cooperative Learning Model and Parenting Styles to Students' Speaking Capability
}

\author{
Nyta Permatasari Situmorang \\ Post Graduate Program Universitas Negeri Medan \\ Universitas Negeri Medan \\ Medan, Indonesia \\ gemsari_npssitumpeople@yahoo.com
}

\begin{abstract}
This study demonstrates the effect of cooperative learning model and parenting styles on speaking capability. The author examined that different parenting style will lead different speaking ability. The aims of this paper are to determine the students' speaking ability which are taught with Talking Stick and Number Head Together, determine the students' speaking ability of students who have experience in Permissive, Authoritative, and Authoritarian, determine the interaction between cooperative learning model and Parenting Style in students' speaking ability. The study population was second class of Junior High School in Panei. Samplee selection is done by cluster random sampling and the method is $2 \times 3$ factorial research design Data analysis technique used Two ways Analysis of Variance at significance level is 0,05 which continued with Scheffe Advanced Test. Hypothesis testing result The average value of the students English learning result which are taught with the Number Head Together cooperative learning model was higher than those who are taught with the Talking Stick, The average value of the students' speaking ability of students who have experienced in authoritative parenting style was higher than the students English learning result who have experienced in authoritarian and permissive parenting style and there was interaction between learning model and parenting style in learning to the students' speaking ability.
\end{abstract}

Keywords: Cooperative learning model, parenting styles, speaking ability

\section{INTRODUCTION}

Education is one of the most important aspects in this life. Education is a universal activity in human life. Education is a sector that greatly determines the quality of a nation. In other words we can conclude that education is one of the efforts to improve human intelligence and skills. Therefore education is also mentioned as a main part in nation building. The failure of education has huge impacts for the failure of a nation and even the success of education also automatically brings success to a nation. Education requires special attention from all walks of life, not only the government but all parties, teachers, parents and students themselves. Education is seen as a high-quality as human resources. High quality resources are interpreted as modifying resources because in this, people must be able to compete because all opportunities are open to anyone. In the pursuit of life success, there will be intense competition; therefore human resources are needed, which are reliable, namely Human Resources who have the expertise, tenacity, honesty and hard work. Human Resources who do not have these qualities will lose in competition. One of the proof to be a high quality human resources is the understanding of languages. English is one of them. English is a worldwide language spoken throughout all parts of life.

Language learning will enable everyone to communicate well because in essence, language is the main tool in communicating. To meet needs, people must communicate. Therefore language is very important for human life. Without language we cannot communicate with fellow humans and cannot meet needs. And one of the languages that supports is English. This subject must be studied by students because its role serves as a communication medium. In the regulation of the Minister of National Education number 22 of 2006 (BSNP, 2006) explained that English is a tool for communicating verbally and in writing. The communication was developed through four language skills, namely, reading, writing, listening, and speaking. Like 2015 MEA (Asean Economic Community) has entered our country Indonesia. The existence of a Free Market or MEA (Asean Economic Community) indirectly demands that we as a society be competent and competitive in all aspects. Indonesia must rely more on professional human resources and can no longer only rely on natural resources and physical ability to achieve the welfare of its people. One of the conditions to achieve this is the ability of English; we are required to be able to communicate in this language. Mastery of English is very important because almost all global information in various aspects of life uses this language. But in reality, in Indonesia, the target of achieving English proficiency in students is still categorized as low, including in the aspect of speaking. The aspect of speaking will direct students to the smooth communication and also increase the interaction of fellow students. In the national scope, there is still an understanding that English is used when teaching and learning only. Apart from learning in class, the use of English is neglected. On the other hand, the mindset that considers learning English is very difficult to learn is also an indication of the achievement of students' low English proficiency.

Survey TEFLIN which announced that TEFLIN Institute is an institution engaged in the study of English language education in Indonesia. TEFLIN considers that English language education is directed to memorization and not 
towards communication. The same thing was also stated by an English survey that announced the results of a global English Proficiency Index survey or Index of English Language Ability in Indonesia in 2016 with an Indonesian score of 52.94. Of the 72 countries surveyed, Indonesia ranked 32nd. If seen from Asian countries, Indonesia ranked $8^{\text {th }}$. This is in line with the low English learning outcomes. In a national scale, it can be seen that the value of subjects in the implementation of the National Examination for junior high schools in Indonesia in 2016 is still low. When viewed on a regional scale, the value of English subjects is still low. So, it can be concluded that the value of English subjects at junior high school education level is still on a low scale.

The measure of students' success in learning material is shown in terms of value/score. The success or success of a student in learning can be seen from student learning outcomes. In education, students will be assessed for their success through tests of learning outcomes and their implementation. Expected results are optimal learning achievement as expected by teachers, schools, and parents. Among students one with other students is different in learning achievement. There are those who are able to achieve high achievement, but there are also students who have low learning achievement.

By seeing this, a learning model is needed to make students active so that their application will be implemented not only in the classroom but also outside the classroom. The learning model that includes student activity is NHT (Number Head Together). NHT (Number Head Together) is one of the cooperative learning methods. According to Slavin (Tukiran Taniredja, 2012) cooperative learning is a learning model in which the learning system and work in groups small groups totaling 3-5 people collaboratively so as to enable students to participate more actively in learning. Collaborative it is defined as a philosophy of personal responsibility and respect for others. Students are responsible for their own learning and try to find information to answer questions. The questions faced by them and the teacher only acted as facilitators. On the other hand, the Talking Stick model is a model that activates students to be responsible for mastering the material in innovative ways. Each group will later issue ideas so that the learning experience becomes longer. Cooperative learning, in this case the Number Heads Together (NHT) learning model and the Talking Stick learning model is a group learning model that works as a team in solving English problems or completing certain tasks. The existence of this active learning model can provide an overview of the application of learning outcomes in language learning, in this case learning English in real life is expected that language learning itself is more meaningful.

One factor that is very important is the role of parents. It means that the importance of good relationships between parents and children affects the development of children, including in learning activities. This condition causes the value of student learning outcomes still a lot below average. It is known that education consists of three educational environments called the education trilogy, namely education in the family, school, and also the community. These three educational environments must work together to improve the learning process experienced by students. Of the three educational environments, education in the family is the first education experienced by children. So that the education that occurs in the family should be done well, so that the education received by the next child can run well too. Education provided by parents in the family environment for their children can occur from parenting patterns given by parents to their children. Parenting patterns must be in accordance with children's needs so that children can develop well and optimally. If this happens then the achievement in the learning process that will be experienced by the child will run more optimally. Basically learning achievement can be influenced by several factors, namely internal factors and external factors. Internal factors are factors that come from within the child itself.

The role of education in schools will be more successful if there is participation from parents in guiding their children to want to learn better and regularly. The family should be the first and foremost educational environment for children. Family education is also an educational environment that leads to moral attitudes that have relationships with other knowledge (Fatimah 2006). Education obtained from the family will determine the achievement of student learning outcomes. This was confirmed by Slameto (2010: 61), namely that parents who lack / do not pay attention to their children's education, for example, they are indifferent to their children's learning, do not pay attention to their children's interests and needs in learning, do not manage time learning, not providing / completing learning tools, not paying attention to whether children learn or cannot cause children not / less successful in learning. Gordon in his book becoming an effective parent explained that parents have a very crucial role in the formation of a child. This will have a major impact on problem solving, social life, acceptance will be around and especially acceptance of yourself. This is also what will affect the child's learning process. Children will be easy or difficult in following the learning process in school if the parenting patterns of children do not go as they should. Therefore, families have important and strategic meaning in the development of a wider community. Harmonious family life needs to be built on the basic system of interaction is conducive so that education can take place well.

\section{METHOD}

This research was conducted in SMP Negeri 1 Panei in class 7th grade in the academic year 2017 / 2018. The population in this study is all students of class 7 th grade SMP Negeri 1 Panei 6 classes year 2017/2018 classes of classes 7th grade A until 7th grade F consist of students 192 students. The sampling technique in this research is by cluster random sampling technique, class 7 th grade $\mathrm{A}$ amounted to 30 students of the class given the learning with NHT (Number Head Together) model and $7^{\text {th }}$ grade $\mathrm{F}$ amounted to 30 
students of the class given the learning with Talking Stick model at SMP Negeri 1 Panei.

The method used in this research is the experimental method (quasi experiment). The research design used is the factorial design $2 \times 3$, which compares the model of learning in NHT (Number Head Together) and Talking Stick model scientific to role of the parenting style type permissive, authoritative, and authoritarian.

Technique data collection in this study is to use test and questionnaire techniques. The test is used to obtain English learning result data and questionnaire to determine student personality type. The test is used to obtain student data of English learning result. The form of English learning result test used is speaking test about the students and the things around their house and classroom. Test results of learning English conducted as many as 20 questions. Questionnaire type personality developed from Florence Littauer in his Personality Plus. The instruments in the study used indicators in each personality type. Questionnaires are created so that students must choose the appropriate statement by giving a check list $(\sqrt{ })$. The questionnaire scale used is likert scale with five choices. The instrument test is performed to obtain valid and reliable research instruments. The goal is to see whether the instrument is capable of measuring what should be measured (validity) and reliability of the instrument (reliable). The research design we can see as below:

\begin{tabular}{|c|c|c|}
\hline \multicolumn{1}{|c|}{ TABLE I. Research Design } \\
\hline \multirow{2}{*}{\begin{tabular}{c} 
Parenting Style \\
\cline { 2 - 3 }
\end{tabular}} & $\begin{array}{c}\text { Number Hearning Model (A) } \\
\text { Together }(\mathbf{N H T}) \\
\left(\mathbf{A}_{1}\right)\end{array}$ & $\begin{array}{c}\text { Talking Stick } \\
\left(\mathbf{A}_{2}\right)\end{array}$ \\
\hline $\begin{array}{c}\text { Authoritarian } \\
\text { (B1) }\end{array}$ & $\mathrm{A}_{1} \mathrm{~B}_{1}$ & $\mathrm{~A}_{2} \mathrm{~B}_{1}$ \\
\hline $\begin{array}{c}\text { Authoritative } \\
\text { (B2) }\end{array}$ & $\mathrm{A}_{1} \mathrm{~B}_{2}$ & $\mathrm{~A}_{2} \mathrm{~B}_{2}$ \\
\hline $\begin{array}{c}\text { Permissive } \\
\text { (B3) }\end{array}$ & $\mathrm{A}_{1} \mathrm{~B}_{3}$ & $\mathrm{~A}_{2} \mathrm{~B}_{3}$ \\
\hline
\end{tabular}

A1B1 : English learning outcomes are taught by Number Head Together learning model to students with authoritarian parenting style

A1B2 : English learning outcomes are taught by Number Head Together learning model to students with authoritative parenting style

A1B3 : English learning outcomes that are taught by Number Head Together learning model to students with permissive parenting style

A2B1: English learning outcomes are taught by Talking Stick learning model to students with authoritarian parenting style

A2B2: English learning outcomes that are learned by communicative approach to students with authoritative parenting style

A2B3 : English learning outcomes learned by communicative approaches to students with permissive parenting style

The techniques of data analysis used were descriptive and inferential statistical technique. Descriptive statistical technique was used to describe the data include: average value, median, mode, variance and standard deviation. The inferential technique to be used was the data analysis technique of variance (ANAVA) $2 \times 2$. Hypothesis testing would be performed at $5 \%$ significance level. Before the twoways ANAVA were performed, the requirement analysis test was performed first by using normality test and Liliefors test and homogeneity test by using Fisher test and Bartlett test.
To test the hypothesis, formulated statistical hypothesis as follows:

a. The first hypothesis

Ho: $\mu \mathrm{A} 1<\mu \mathrm{A} 2$

Ha: $\mu \mathrm{A} 1>\mu \mathrm{A} 2$

b. The Second Hypothesis

Ho: $\mu \mathrm{B} 1=\mu \mathrm{B} 2=\mu \mathrm{B} 3$

Ha: $\mu \mathrm{B} 1 \neq \mu \mathrm{B} 2 \neq \mu \mathrm{B} 3$

c. The Third Hypothesis

Ho: $\mathrm{A}><\mathrm{B}=0$

Ha: $\mathrm{A}><\mathrm{B} \neq 0$

\section{RESEARCH RESULT}

The first, second and third hypothesis testing was performed by using two-ways ANAVA. The summary of the calculation results could be seen in Table 2 below.

\begin{tabular}{|c|c|c|c|c|c|}
\hline \multicolumn{7}{|c|}{ TABLE II. Hypothesis Data } \\
$\begin{array}{c}\text { Sources of } \\
\text { Variation }\end{array}$ & $\mathbf{d k}$ & $\mathbf{J K}$ & $\mathbf{R J K}$ & $\mathbf{F h}$ & $\mathbf{F t}$ \\
\hline & & & & & \\
\hline A & 1 & 742,02 & 742,02 & 27,10 & 4,0 \\
B & 2 & 521,07 & 521,07 & 19,03 & 3,1 \\
AB & 2 & 458,11 & 458,11 & 16,73 & 3,1 \\
Galat & 54 & 1.643 & 27,38 & & \\
\hline Total & $\mathbf{5 9}$ & $\mathbf{3 . 3 6 4 , 1 8}$ & & & \\
\hline
\end{tabular}

Description:

A : Learning model

B : Critical Thinking Skills

$\mathrm{dk}$ : Degree of freedom

JK : The sum of squares

RJK : The mean sum of squares

Based on the results of the first hypothesis testing then the results of hypothesis calculation obtained $\mathrm{F}$ calculated = 27.10. For the distribution value $\mathrm{F}$ table $=4.0$ then this result indicates that $\mathrm{F}$ calculated $>\mathrm{F}$ table so as to give decision that Ho rejected and Ha accepted. Thus, the proposed research hypothesis that the result of speaking capability class Number Head Together is higher than the result of speaking capability students class Talking Stick. From the results of the second hypothesis calculation obtained $F$ count $=19.03$. For the value of the distribution $\mathrm{F}$ table $=3.1$ then this result shows that $\mathrm{F}$ calculated $>\mathrm{F}$ table so as to give a decision that Ho rejected and Ha accepted. Thus, the research hypothesis proposed that there are differences in speaking capability outcomes of students with authoritative parenting style with the result of students' speaking capability with the style authoritarian and permissive.

From the results of the third hypothesis calculation obtained $\mathrm{F}$ count $=16.73$. For the value of the distribution $\mathrm{F}$ table $=3.1$ then this result shows that $F$ calculated $>F$ table so as to give a decision that Ho rejected and Ha accepted. Thus, the proposed research hypothesis that there is interaction between learning model and parenting style to English learning outcomes in speaking capability. 


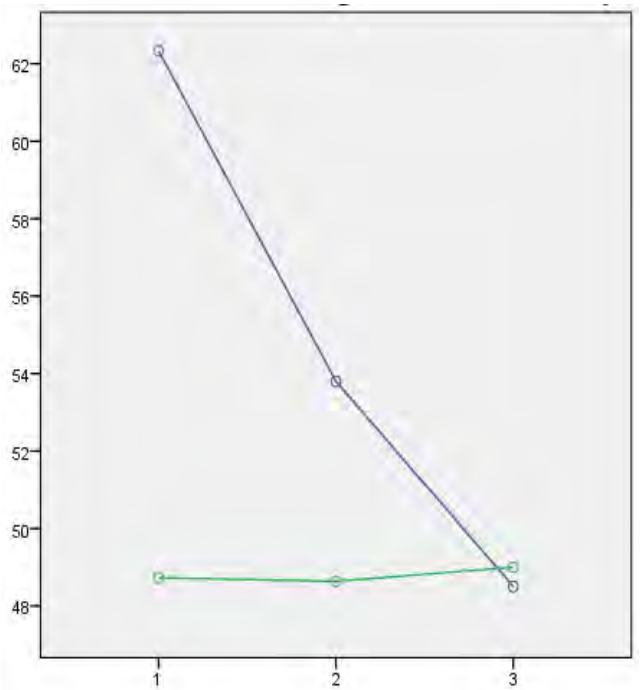

"Fig 1. Interaction learning approach and personality type"

\section{REFERENCES}

[1] Alsheikh, N., P., G, \&Elhoweris, H. (2010) Parenting Style, Selfesteem and Student performance in the United Arab Emirates. Current Issues in education, (13). ISSN: 1099-839X

[2] Wardana, Ludi (2016). Paper Airplane and Talking Stick Learning Methods to Increase Students Understanding About Management Information System Courses IQSR Journal of Business and Management.(18), 164-169. ISSN: 2278-487X

[3] Bibi, F., Chaudry, G. A., Awan, E., Tariq, B.(2013).Contribution of Parenting Style in Life Domain of Children.Journal of Humanities and Social Science,(12), 91-95. ISSN: 2279-0837.

[4] Carey, Dick Walter, Lou Carey \& James. O. Carey. 2009. The Systematic Design of Instruction $\left(7^{\text {th }}\right.$ ed). Newyork: Pearson.

[5] Driscoll, Marcy P. 2000. Psychology of Learning for Instruction. Florida State University

[6] Fraenkel \&Wallen. 2008. How to Design and Evaluate Research in Education.New York: McGraw-Hill

[7] Gall, Meredith, D., Gall, Joyce, P., Borg, Walter, R. 2007.Educational Research. New York: United States of Amerika

[8] Hurlock, Elizabeth. 1978. Child Development Sixth Edition (diterjemahkan oleh Meitasari). Jakarta: Erlangga 